\title{
ERRATUM
}

\section{The Cadmium Content of British Wheat Grain}

A.M. Chaudri, F.J. Zhao, S.P. McGrath, and A.R. Crosland; J. Environ. Qual. 24:850-855 (1995).

The German limit for $\mathrm{Cd}$ in wheat grain of $0.1 \mathrm{mg}$ $\mathrm{kg}^{-1}$ fresh wt. (0.12 $\mathrm{mg} \mathrm{kg}^{-1}$ dry wt.) (BGA, 1986) has been mistakenly labeled as the WHO limit in the above paper. There is as yet no $\mathrm{FAO} / \mathrm{WHO} \mathrm{Cd}$ in wheat grain limit.

\section{Reference}

BGA (Bundesgesundheitsamt). 1986. Richtwerte ' 86 für Blei, Cadmium und Quecksilber in und auf Lebensmitteln. Bundesgesundheitsblatt 29:22-23. 